\begin{tabular}{|c|c|}
\hline & $\begin{array}{l}\text { International Journal of Trend in Scientific } \\
\text { Research and Development (IJTSRD) }\end{array}$ \\
\hline 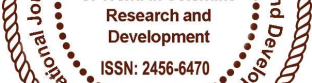 & International Open Access Journal \\
\hline 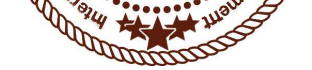 & ISSN No: 2456 - 6470 | www.ijtsrd.com | Volume - 2 | Issue - 2 \\
\hline
\end{tabular}

\title{
Organising the Unorganised Unprofessional Daily Wage Earners Who Provide Services at Home - A Study Made in Guwahati City of Assam
}

\author{
Sangita Das \\ Ph.D Research Scholar, Department of Commerce, \\ Gauhati University, Guwahati, Assam, India
}

\section{ABSTRACT}

Unorganised workers have been facing tremendous problems since ages. Right from financial security to health safety they have to fight for uncountable problems. Despite of enforcement of various laws and regulations for the security of labourers, only few of the workers working in unorganized sector are availing the benefit.

Here, through this research paper the Researcher tries to give importance on organizing the unorganized daily wage earners who provide services at home only excluding other professional service providers and the problems faced by them so that they can avail the benefits of various acts and laws by understanding their rights properly in an organized manner.The entire study is based on primary data collected at source.

Keywords: Labour, Unorganised, Daily wage earners, Laws, Regulations

\section{INTRODUCTION}

In India ,a major part of the working population work in unorganized sector. Almost $92 \%$ of the workforce is in the unorganized sector. Unorganised sector brings an opportunity for the unemployed youths to live their livelihood. As per National Sample Survey Organisation (NSSO)in 2009-2010, the total employment in the country was of 46.5 crore comprising around 2.8 crore in organized and remaining 43.7 crore workers in the unorganized sector. The Ministry of Labour, Government of India has categorized the unorganized labour in terms of occupation, nature of employment, specially distressed categories and service categories.

Under terms of occupation

- Small and marginal farmers, landless agricultural labourers, share croppers, fishermen, those engaged in animal husbandry, beedi making, labeling and packing, building and construction workers, leather workers, weavers, artisans, salt workers, workers in bric kilns and stone quarries, workers in saw mills, oil mills etc.

Under terms of nature of employment

- Attached agricultural labourers, bonded labourers,migrant workers, contract and casual labourers come under this category.

- Under terms of specially distressed category

- Toddy tappers,scavengers, carriers of head loads,drivers of animal driven vehicles,loaders and unloaders come under this category

Under terms of service category

- Midwives, domestic workers, fishermen, barbers, vegetable and fruit vendors, newspaper vendors belong to this category.In addition to these four categories, there exists a large section of unorganized labour force such as cobblers, hamals, handricraft artisans, handloom weavers, lady tailors, rikshaw pullers , auto drivers, 
sericulture workers, carpenters, tannery workers, power loom workers and urban poor.

Though they have been victimized for financial and social security problems for a long period,they are constantly providing their valuable services in this sector of the economy just for the sake of empty stomachs.Unorganised daily wage earners are the people who provide various services at home and works on daily wage rate system. They are generally unprofessional service providers and always search for their works by roaming here and there. These workers are generally found in the form of carpenter, mason, and other daily wage earners etc. There are some particular area in Guwahati city where they are found with their utensils. They wake up early in the morning and stand in nearby city bus stoppages in various area of Guwahati and wait for the prospective commuters. Then the people who are in need of these workers come to that place and starts making bargaining with them regarding for the daily wages and somehow they manage the workers to work in their house at a very cheap rate. The workers are also ready to do so only because they have no option left as they are in need of money as well as they cannot raise voice against their exploitation as they are very illiterate and unaware about the various laws and legislations and they don't work under any union also.

\section{Objectives}

1. to study about organizing the unorganized daily wage earners through a proper channel

2. to study about various problems faced by unorganized daily wage labourers

3. to examine the role of government and other agencies in this case i.e how they are contributing to solve various issues of unorganized daily wage labourers.

\section{REVIEW OF LITERATURE:}

A number of research studies have been carried out on unorganized labour problems in India and Abroad. It embodies various articles, research publications, working papers etc. Some of these are mentioned below which help the researcher to find out the research gap in earlier studies.

- Gangrade and Gathia (1983) studied the problems faced by women workers in informal sector including low wages,long hours of work, insecurity regarding job, sexual harassment etc. Despite of facing such problems women were working in this sector to support the family income.

- Manohar(1983) discussed the exploitation of women workers in unorganized sector with reference to male dominance.

- Bandyopadhyay and Hillary(1985) studied the increasing number of women in Kolkata labour force because of high rate of male unemployment, falling living urban standards etc.

- Anand(1988) in his study pointed out the migrant women informal labourers from Tamil nadu to Delhi easily get job opportunitry as compared to male counterparts. The occupation they enter are mostly informal sector.

- Biswajit Ghosh (1988) in his study discussed the measures adopted by the trade unions in organizing the unorganized workers in the leather and bookbinding industries in Calcutta

- Saran and Sandhwar(1990) in their study pointed out the problems faced by women workers of unorganized sector of brick kilns, quarries and mines of Bihar and West Bengal.

Shaw(1990) analysed the interconnection between informal and large scale sectors in Thana Belapur region where he found that large units have important forward linkage with informal sector units but unfortunately the informal sector workers face health related risks.

- Banerjee(1991) studied the impact of new export oriented industries on women workers in India and concluded that women working unskilled work,worked for long hours under miserable working conditions in those industries .

- Kundu(1993) in his study pointed out the higher growth rate of informal sector in urban areas as compared to the growth rate of organized sector in rural areas in the states like West Bengal,Maharastra and Gujrat.

- Guhan (1994) discussed the importance of protective type of programmes like old age pension,maternity leave etc for unorganized workers.

- David(1996) discussed the structure and composition of urban unorganized sector.He found workers working in unorganized sector faced the problem of insecurity,no legal protection, long working hours and paid less amount of money as compared to their work.

- Funkhouser(1996) examined the patterns of employment and structure of earning in urban informal sector on five American countries.He 
found negative relationship between levels of education and informal sector employment and higher probability for poor family to get employed in informal sectors.

- Sundaram(1996) projected women workers in unorganized sector were generally illiterate,had high employment rate as compared to men in this sector and worked under exploitive working conditions.

- Gajalakshmi (1998) analysed the informal women workers engaged in shoe factories in Tamil Nadu are from backward classes and scheduled castes. They earned low income, live in poverty and work or long hours.

- Sharma(1998) analysed the linkage between formal informal sector and different modes of production.

- K. Deka(2001) studied the social security measures foe unorganized agricultural labourers of Kamrup district.

- Anand(2003) outlines the policy framework necessary for informal sector developmentin India.

- Pushpaganda and Shanta(2004) discussed the growth of informal sector in India during 1993 to 2000 and concluded that the recent growth has occurred independent of efficiency gains and therefore its competitiveness is questionable, especially in reference to the impact// of globalization.

- Thomas G(2006) analysed the problems faced by urban unorganized labourers in Kerala.

- Rogaly Ben (2009) studied the spaces of work and everyday life:labour geographyies and agency of unorganized temporary migrant workers who are always neglected in labour geography.

- Neeru Gupta(2010) studied about the unorganized manufacturing sector in India during postliberalisation period.

- R Muthuswamy (2011) in his study mentioned about the social security measures and welfare schemes for unorganized workers in namakkal district.

- Deepjyoti Choudhury (2012) in his study mentioned about organizing the unorganized sector workers in North east region through a logistic model.

- P Sarkar,Amir Jafar and Amitava Ghosh(2012) in their study pointed out the various aspects of trade unions response with respect to the different categories of unorganized workers in India.
- Reeta D Sauza(2013) studied about the domestic workers ,problems faced by them in Silchar town of Assam

- Deepika Das(2014) studied about the women unorganized workers in palashbari revenue circle of Kamrup district of Assam, She mentioned the various problems faced by the workers in working place like low wages, exploitation, long working hours etc.

- Gnanamanickom (2015) in his study mentioned about the problems and prospects of unorganized labour force in border roads organization in Assam.

- Himangini Sharma(2017) in her study attempted to analyse the the problems faced by the unorganized labourers and welfare measures adopted by their employer and government.

\section{RESEARCH GAP:}

After studying the available literature about unorganized labourers the researcher found that no initiative was taken in organizing the unorganized daily wage earners of Guwahati is taken yet. However no thinking is given yet to solve the labour problems through the use of internet i.e, by developing an online app.

\section{RESEARCH METODOLOGY}

\section{Source of data:}

The research is based on primary data and secondary data. Primary data are collected from the source itself by interviewing the labourers with the help of a schedule. And secondary data are collected from various journals, newspapers, internet etc.

\section{Population}

The unorganized daily wage earners providing services at home excluding the professional service provider of entire guwahati city is the population of the study.

\section{Sample}

A sample of 100 workers are collected by using convenient sampling technique by the researcher

Findings/ problems of unorganized daily wage earners

1. Low wage rate: Most of the unorganized daily service providers working in Guwahati are found in some specific area including zoo road tiniali, 
silpukhuri, serabbhatti, etc searching for work on daily basis. They come in the early morning and wait for the employer. Then the needed people come and start bargaining with then regarding their wage rate and convince them to work on a very low rate of wages. The workers are complelled to do so only for the sake of their livelihood. Most of the workers said that they often work on a daily wage rate which is much cheaper than the rate prevailing in the market.

2. Unawareness of the workers: Secondly the found that most of the unorganised daily service providers are illiterate. They donot have much knowledge about the laws, acts and all.So, its been easier for the people to cheat them. However they are completely unaware about the various issues relating to their safety and security.

3. Assam government has taken certain initiative by issuing job cards to the daily wage labourers of rural areas.

4. These uorganised unprofessional daily wage earners are not registered in any trade unions.

\section{CONCLUSIONS:}

If these workers are brought in an organized platform by registering them under certain unions or agencies so that these agencies will manage to search their day to day work by considering their financial and health security measures. If government will take such initiatives then these workers will be easily benefited. First of all the workers need not to search for work on daily basis by roaming here and there and secondly they will get proper wages without any difficulty and thirdly they can raise their voices against exploitation as they will get full support of the union as well as government. Here a question may come regarding the running of such unions or agencies which are not getting government funds to run their functions. In this case if if one labour contribute minimum of Rs 23 then on daily basis, it would be sufficient to maintain and run such agencies. This will help the users of such workers also as they will be able to identify each and every labourers employed in their home to work on daily wage basis. Various government organizations should show their responsibility towards these workers . for eg if GMDA(Guwahati Municipal Development Authority) can collect taxes before constructing a building it is their responsibility to look after the safety of labouerers working on that particular construction site.

\section{REFERENCES}

1. Gangrade and Gathia (1983),Women and child workers in Unorganised sector, Non govt. organization perspectives, Concept publishing company, New Delhi,p.104

2. Manohar ,K.M (1983), Socio Economic Status of Indian Women,Sage Publications,New Delhi.

3. Bandyopadhyaya Bela and Standing Hillary(1985),Women's employment and household-some findings from Calcutta,Economic and Political Weekly,Vol.20,No. 7

4. Bannerji, N.(1985) Women Workers in the Unorganized Sector:The Calcutta experience. Hyderabad:Sangham Book private Ltd

5. Anand, I. (1988), Migration and Adaption:Lower caste Tamils in Delhi Resettlement Colony,Sociological Bulletin,No. 37,pp 113-126

6. Ghosh,Biswajit.1988, Organising unorganized workers : a sociological study of trade unionism in the leather and bookbinding industries in Calcutta,JNU

7. Saran, A.B and Sandhwar, A.N(1990), Problems of women workers in unorganized sector(brick kilns, Quarries and Mines of Bihar and West Bengal),Northern Book Centre,New Delhi

8. Shaw,A(1990) Linkage of Large scale Small Scale and Informal sector industries: a study of Thana Belapur, Economic and Political Weekly, Vol 25, No.7

9. Banerjee, N. (1991),Indian women in changing Industrial Scenario,Sage Publications, New Delhi.

10. Kundu , A(1993),Urban informal sector:an overview of macro dimensions, socio-economic correlates and policy perspectives in India,in H.Nagamine(ed) Urban informal sector employment: A cross national comparative study, Research Institute for Regional Planning and Development,Nagoya 
11. Guhan ,S.(1994), Social security options for developing countries, International Labour Review,Vol.133,N0.1.

12. David(1996),Unorganised women workers: Problems and Prospects,Tripathi(ed ), unorganisedwomen labour in India, discovery publishing House,New Delhi

13. Funkhouser, Edward(1996), The urban informal sector in central America:Household Survey Evidence,World Development, Vol. 24

14. Sundram ,Satya(1996) Plight of unorganized women workers, Tripathi(ed ), unorganisedwomen labour in India, discovery publishing House,New Delhi

15. Gajalakshmi ,N (1998) Problrms and prospects of women labour in India, Mohit publications, New Delhi

16. Sharma(1998) informal sector-irrelevance or Voguism:An overview, Margin,Vol. 34, No.1.

17. Deka,K.2001 A study of social security for the unorganized sector workers in Assam with special reference to the agricultural labourers of Kamrup district, Gauhati University

18. Anand, V(2003) Policy package for informal sector Development:Basic Assumptions, Indian journal of economics, Vol. 84, No.333

19. Pushoangadan, K and N. Shanta(2004), growth and efficiency of the informal sector in India: a non parametric analysis, Labour and development ,Vol.10.No.1.

20. Thomas G.2006. Urban Informal Sector in Kerela

21. Rogaly,Ben.2009 Spaces of work and everyday life:labour geographies and the agency of unorganized temporary migrant workers.Geography Compass,3(6).pp. 19751987.ISSN 1749-8198

22. Dutta,Pranati.2010 Domestic workers in Assam to get minimum wages.www.newageweekly.com/2010/09/domestic workers-in-assam-to-get.htm
23. Gupta,Neeru(2010) Unorganised manufacturing sector in India during post liberalization period, Punjabi University

24. Muthusamy.,R.2011.A Study on social security and welfare schemes of the unorganized workers in Namakkal Dist,Periyar University

25. Choudhury,Deepjyoti.2012 Organising the unorganized sector:An ICT Enabled Logistics Model in Favour of Cottage and Small Scale Industries in Northeast India,Pacific Business Review International, Volume 5 Issue 2

26. Sarkar,P ,Jafar, A and Ghosh Amitava.2012 Organising the unorganized: Trade union response vis-à-vis the unorganized sector in India,University of Burdwan

27. D Souza,Reeta,2013 A study of women domestic labour in Silchar town, Assam University

28. Das,Deepika.2014 Women labour in the unorganized sector a study in palashbari revenue circle of Kamrup District in Assam, Gauhati University

29. Gnanamanickam,2015.Problems and prospects of unorganized labour force in border roads organization with reference to assam an empirical study,Manonmaniam Sundaranar University

30. Sharma,H. 2017.The Analysis of problems of unorganized labour-a review, Department of Management Studies,University of Kota

31. Shodhganga.inflibnet.ac.in

32. Wikipedia 